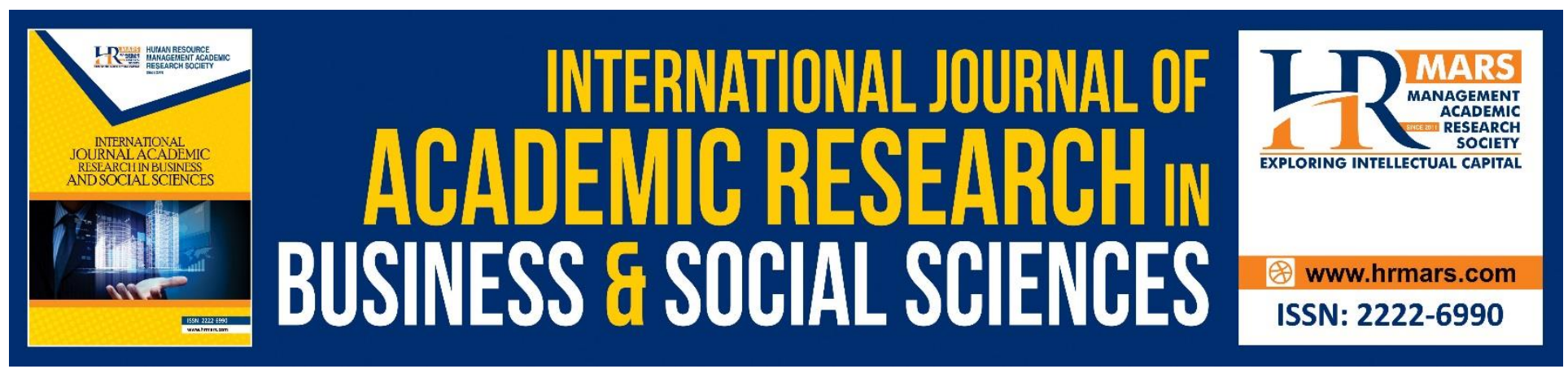

\title{
Tweet Teach to Enhance Reading Skill among Low Proficiency Pupils
}

Siti Noor Fadilah Mustaffar, Nurul Qistina Baharuddin and Melor Md Yunus

To Link this Article: http://dx.doi.org/10.6007/IJARBSS/v9-i1/5462

DOI: $\quad 10.6007 /$ IJARBSS/v9-i1/5462

Received: 22 Dec 2018, Revised: 14 Jan 2019, Accepted: 27 Jan 2019

Published Online: 16 Feb 2019

In-Text Citation: (Mustaffar, Baharuddin, \& Yunus, 2019)

To Cite this Article: Mustaffar, S. N. F., Baharuddin, N. Q., \& Yunus, M. M. (2019). Tweet Teach to Enhance Reading Skill among Low Proficiency Pupils. International Journal of Academic Research in Business and Social Sciences, 9(1), 609-619.

Copyright: (C) 2019 The Author(s)

Published by Human Resource Management Academic Research Society (www.hrmars.com)

This article is published under the Creative Commons Attribution (CC BY 4.0) license. Anyone may reproduce, distribute, translate and create derivative works of this article (for both commercial and non-commercial purposes), subject to full attribution to the original publication and authors. The full terms of this license may be seen

at: $\underline{\text { http://creativecommons.org/licences/by/4.0/legalcode }}$

\section{Vol. 9, No. 1, 2019, Pg. 609 - 619}

Full Terms \& Conditions of access and use can be found at http://hrmars.com/index.php/pages/detail/publication-ethics 


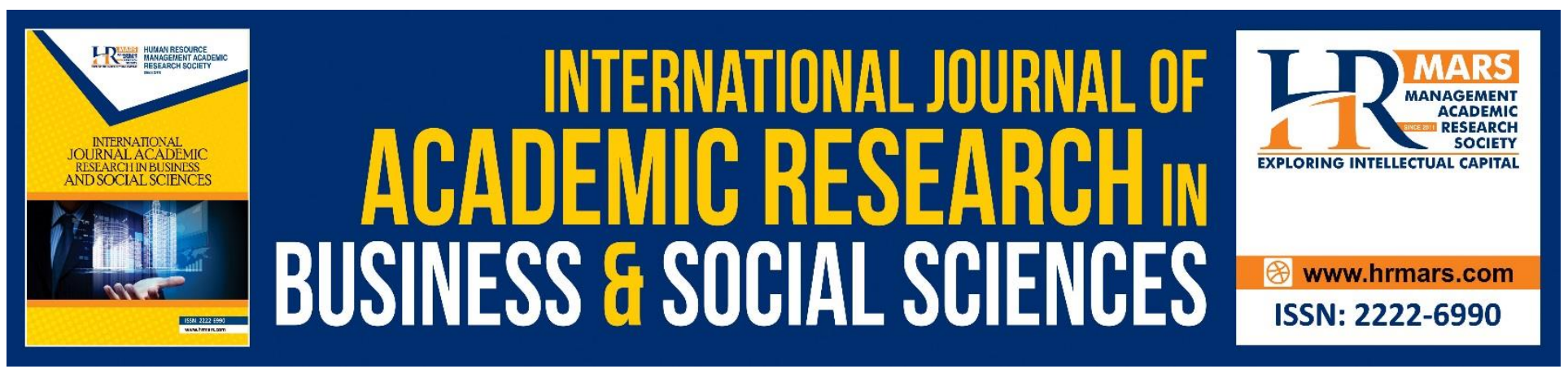

\title{
Tweet Teach to Enhance Reading Skill among Low Proficiency Pupils
}

\author{
Siti Noor Fadilah Mustaffar, ${ }^{1,3}$, Nurul Qistina Baharuddin ${ }^{2,3}$ and \\ Melor Md Yunus 3 \\ ${ }^{1}$ Sekolah Kebangsaan Ayer Merbau, Jasin, Malacca, Malaysia \\ ${ }^{2}$ Sekolah Kebangsaan Seri Gemilang, Butterworth, Penang, Malaysia \\ ${ }^{3}$ Faculty of Education, National University of Malaysia, Selangor, Malaysia
}

\begin{abstract}
Reading skill is important for young learners. The incompetence of reading skill may affect young learners' progress in learning. However, in the modernisation of today's gadgets' world, many young learners are competence to use the ICT even though they can't read properly. A similar problem was identified among low proficiency of Level 1, who are also the participants of LINUS programme in Butterworth, Penang and Jasin, Malacca. Therefore, an action research of Ebbutt was conducted to investigate the enhancement of reading skill and their perception using Tweet Teach. Tweet Teach is an innovative teaching and learning tool innovated from a trendy and free social media, Twitter to teach phonics and vocabulary. There are 2 modules, the 'Tweet Sound' and 'Tweet Pic-a-Thing'. 5 pupils of low proficiency of K3-K12 LINUS were chosen as the participants for this study. The pre-test and post-test, the Likert scale and the interview were used as instruments in the study. The finding of the study had led to an improvement in reading skill and positive perception was given by the participants. Overall, the use of Tweet Teach and its modules enhanced the reading skill among low proficiency pupils of Level 1.
\end{abstract}

Keywords: Reading, Low Proficiency, ICT, Social Media, Twitter

\section{Introduction}

The English language is the Malaysians' second language. The language is being taught as a subject in schools from Year 1 primary school to Form 5 secondary school (Murugan Raj, 2014). The importance of the languages is emphasized in the Malaysian Education Blueprint (MEB) 2013 - 2025. In the second shift of MEB, it is to ensure every child to be proficient in Bahasa Malaysia and English Language (Ministry of Education, 2012). The use of ICT among young Malaysian children can be observed in schools, therefore the Ministry of Education also look forward to leveraging the use of ICT through the $7^{\text {th }}$ shift in the MEB. It is to scale up the quality of teaching and learning in Malaysia. 
Nowadays, the use of gadgets is common among young children. According to Nikken and Schols (2015), it is reported the use of game gadgets and computers are significantly increase gradually with age. The gadgets are used at least per day by 0-1 year old, somewhat longer by 2-3 year old, then significantly longer per day by 4-5 year old children, and finally the longest by 6-7 year old children. The usage of gadgets cannot be blocked because both parents and children are too dependent on them. These gadgets keep them in control, stay focus and quiet, have fun and stream age-appropriate graphics, besides as a tool for learning new things and as a medium of communication.

Meanwhile, in Malaysia, the use of gadgets is common among children. This habit of giving gadgets at an early age continued till they enter school hence, this is where the two researchers noticed the rising issue. In both schools the researchers have been teaching, it was observed many pupils of low proficiency especially those from Level 1 were competence in using the ICT but not proficient in reading. Their unproficiency in reading was identified based on their performance in Literacy and Numeracy Screening (LINUS) programme from the year 2017 until 2018. They had passed the K1-K2 but not the K3-K12 reading screening. This was quite surprising for both researchers because these young learners used gadgets and ICT on a daily basis but still unable to read in English. Hence, with the research gap identified in both schools, supported by document analysis from the LINUS programme, both researchers conducted an action research of Ebutt. In the study, the researchers are keen to cope with the issue of low proficiency of Level 1 pupils who are competence in using the ICT but are unable to read English. Therefore, the purpose of the study is to investigate the effect of Tweet Teach on enhancing reading and writing skills among low proficiency pupils of Level 1.

Tweet Teach is innovated from a trendy, free and popular social media, the Twitter. Any social networks including the Twitter are defined as web-based services that allow individuals to create public or semi-public profiles within a bounded system (Yunus \& Salehi, 2012). Not only that, these social networks enable the users to form connection among themselves either to serve the purposes of communicating, transmitting or sharing any academic or non-academic information. The teachers have innovated the Twitter into an educational tool where an account called the 'Tweet Teach' is used to teach reading for lower proficiency pupils of Level 1. The use of Tweet Teach is based on two different modules created by the researchers. The modules are 'Tweet Sound' focusing on phonic awareness and the 'Tweet Pic-a-Thing' where it involves vocabulary learning. In order to facilitate the investigation regarding the relationship of 'Tweet Teach' for teaching reading skill, the researchers formulated the following research questions:

1. How does the Tweet Teach enhance reading skill among low proficiency pupils?

2. What is the pupils' perception of Tweet Teach in enhancing their reading skill?

The modules used via Tweet Teach were intended to teach reading skill. According to Yunus, Nordin, Salehi, Sun and Embi (2013), reading involves the process of decoding words. It is one of the 
important skills in language learning. In the study, the Tweet Teach help to enhance reading skill by creating phonemic awareness and learning simple vocabulary. The first module the 'Tweet Sound' was focusing on phonemic awareness. According to Goldenberg et. all in Fabre-Merchán, Torres-Jara, Andrade-Dominguez and Ortiz-Zurita (2017), the phonemic awareness refers to the ability to understand words that can be broken down into smaller individual units and how to correctly pronounce each phoneme. In this study, the Tweet Teach created the opportunity for the Level 1 of lower proficiency participants to practice their knowledge of English sounds. It helped them to understand the relationship between printed letter and speech sounds. It was also to tone down the fear and anxiety in producing and sound the English sounds. This was because they were non-native speakers and most of them were shy and afraid to use the language. Next, the second module, the 'Tweet Pic-a-Thing' helped to expand the vocabulary content among the participants. As the participants were of lower proficiency, they had limited vocabulary. Therefore, the module provided the maximum attention on twenty-six vocabulary words through spelling. These vocabularies were selected based on the learned sound from the phonics song and pictures from the first module, 'Tweet Sound' posted in Tweet Teach. The relating content between modules helped the participants to comprehend better the target English vocabulary words.

\section{Literature Review}

One of the famous theories related to technology is the technology acceptance model (TAM). It was originally proposed by Davis in 1986. TAM is a theoretical model used to explain and predict the users' behaviour of information technology (Legris, Ingham \& Collerette, 2003). There are two cognitive beliefs posited by the TAM model: perceived usefulness and perceived ease of use. Based on the model, one's actual use of technology is influenced by his or her behavioural intentions, attitude, perceived usefulness of the system and perceived ease of the system. Figure 1 below shows the original technology acceptance model (Davis et al., 1989).

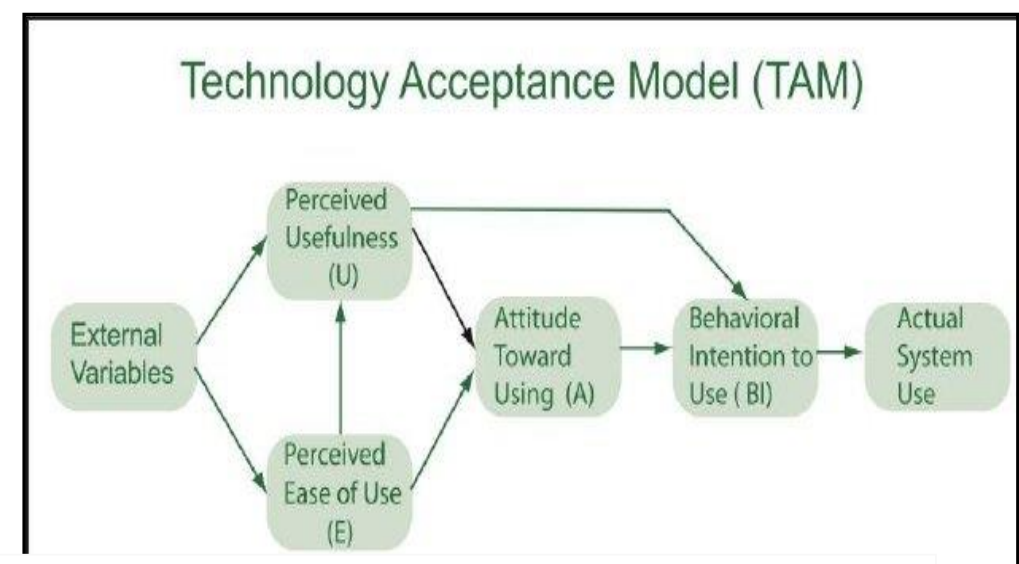

Figure 1. Original technology acceptance model (TAM) 
INTERNATIONAL JOURNAL OF ACADEMIC RESEARCH IN BUSINESS AND SOCIAL SCIENCES

Vol. 9, No. 1, Jan, 2019, E-ISSN: 2222-6990 @ 2019 HRMARS

TAM appears to be able to account for 40 percent to 50 percent of user acceptance (Ibrahim, 2018). Meanwhile, $\mathrm{TAM}_{2}$ extended the original model to explain perceived usefulness and usage intentions including the social influence, cognitive instrumental process and experience.

Constructivism is another theory that suit learning with technology. Learning is achieved by establishing relations between the new knowledge and the knowledge structures that have already existed in the mind. In this study, the use of ICT in learning has encouraged learners to be in a learning environment of exploring and interacting the virtual space supported by the ICT. It helps to generate new knowledge in pupils and finally validate the newly generated knowledge with the help and guidance from their teachers. According to Capacho (2016), in the virtual teaching-learning process, constructivism must be understood not only as a philosophy but also as pedagogy. Constructivist teaching engages the process of social learning to a virtual level. Thus, pupils are committed to use the network in order for them to generate a new concept and contribute to the construction of knowledge. This will help them to understand their problem, negotiating ideas and possible ways to overcome the problem which eventually bring to another new learning experience.

\section{Method}

This research used the Ebbutt's action research. In 1985, Dave Ebbutt had solidified the role of action research in education. According to Ebbutt (Hopkin \& Ahtaridou, 1993), action research is about the systematic study of educational practice by groups of participants by means of their own practical actions and by means of their own reflection upon the effects of these actions. The action research of Ebutt were conducted in both schools, in Malacca and Penang. The instruments and participants were determined and selected as below.

The instruments used in the study were document analysis, the Likert scale survey and the interview. The Likert scale survey was used to measure the participants' perception of the use of Tweet Teach in their learning. Tweet Teach was conducted only with an online connection at school, which happened during school hours. School hour is chosen to create a natural learning setting where the participants may behave and act within their context (Creswell \& Creswell, 2017).

Five participants were randomly selected from Level 1 pupils from the two primary schools in Jasin, Malacca and Butterworth, Penang. Table 1.0 outlined the details of the participants. The pupils were chosen among the low proficient pupils who were involved in LINUS programme administered by the Ministry of Education. They were considered weak in English, especially in reading.

Table 1.0 Basic information about participants

\begin{tabular}{l|lll}
\hline Area & Name & Gender & Age \\
\hline Malacca & Ana & F & 8 \\
& Syaf & M & 8 \\
\multirow{4}{*}{ Penang } & Amar & M & 8 \\
& Tira & F & 9 \\
& Adam & M & 9 \\
\hline
\end{tabular}


INTERNATIONAL JOURNAL OF ACADEMIC RESEARCH IN BUSINESS AND SOCIAL SCIENCES

Vol. 9, No. 1, Jan, 2019, E-ISSN: 2222-6990 (C) 2019 HRMARS

\section{Results}

The results are divided into pre test and post test result, the Likert Scale and the interview transcription.

Pre test and post test result

For this research, the pre test and post test were examined and compared to determine whether Tweet Teach enhancing their reading skill. Raw production test scores were summarized in Table 2.0. The table recorded the participants' scores in pre test and post test for the modules in Tweet Teach.

Table 2.0 Pre test and post test scores of the participants

\begin{tabular}{ccc}
\hline Participants & Pre Test score (\%) & Post Test score (\%) \\
\hline Ana & 50 & 78 \\
Syaf & 44 & 66 \\
Amar & 36 & 54 \\
Tira & 28 & 50 \\
Adam & 48 & 70 \\
\hline
\end{tabular}

From the table shown, all the participants managed to improve their scores in their post test. Based on the post test data collection, the participants managed to get all correct answers for Module 1 , the 'Tweet Sound'. In Module 2 which was 'Tweet Pic-a-Thing', a few errors had been detected in their responses. However, after several attempts made, all the participants were able to get the correct answers. Difficult vocabularies such as 'question' and 'umbrella' required the participants to receive guidance from the researchers. It was evidenced in their post test result that they gained their self-confidence in responding to the tasks given. Throughout the sessions, the participants were guided by the researchers at first, before they completed the modules independently. With the time constraint and limited internet access, the participants managed to complete the modules within a month.

Pupils' perception on using Tweet Teach to enhance their reading skills

The participants were asked to respond to the Likert scale after they completed the Tweet Teach modules. Data analysed from the Likert scale was tabulated in Table 3.0. Table 3.0 shows the responses made by the participants for each statement given. 
INTERNATIONAL JOURNAL OF ACADEMIC RESEARCH IN BUSINESS AND SOCIAL SCIENCES

Vol. 9, No. 1, Jan, 2019, E-ISSN: 2222-6990 @ 2019 HRMARS

Table 3.0 The Likert scale

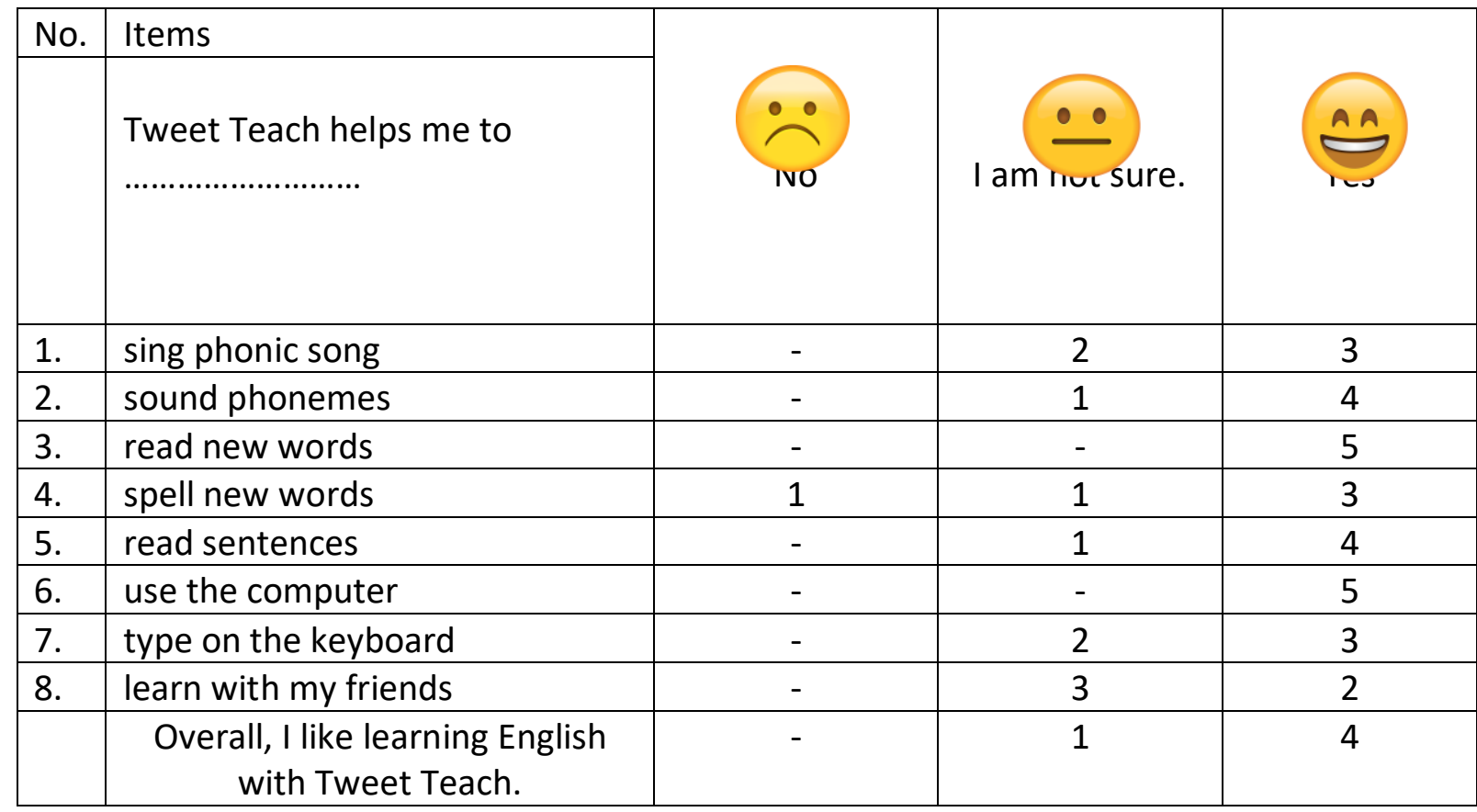

The Likert scale resulted in the majority of the participants were inclined to tick 'yes' in most items. All five participants agreed that Tweet Teach helped them to read new words. Four out of five participants ticked the box that stated they enjoyed using Tweet Teach in reading simple sentences and sounding phonemes. Three of the participants ticked 'yes' in the box that stated they enjoyed singing songs, spelling new words and typing the answers using the keyboard. Four out of five participants liked learning English using Tweet Teach.

Interview transcriptions

From the interview session conducted, the researchers identified some important key points to answer the research questions. The themes were presented and evidenced by the participants' transcription.

i. Tweet Teach affects pupils in reading skills by enhancing their phonics and vocabulary understanding.

By completing the modules, the participants thought that they were able to practice their pronunciation and widen their vocabularies. The participants stated that the modules were helpful in providing ample and suitable practice for their phonics. Their opinions were recorded and transcribed.

The modules help me in improving my spelling and I get to learn new words too. I learn 26 words at one go and the pictures really prompt me in naming the objects or animals based on their 
INTERNATIONAL JOURNAL OF ACADEMIC RESEARCH IN BUSINESS AND SOCIAL SCIENCES

Vol. 9, No. 1, Jan, 2019, E-ISSN: 2222-6990 @ 2019 HRMARS

first letter. (Ana)

I learn some of the words when I see the pictures. I could not believe that I managed to name all the pictures using Tweet Teach. Maybe I can learn another theme by using another set of pictures. (Amar)

The theme was supported with the improvement of the participants' score for post test after they used the modules for reading. In accordance with the Likert scale, most of the participants were recorded stating that they read and learnt new words using Tweet Teach. Four out of five participants said they sounded phonemes better. With the triangulation data of post test, Likert scale data and interview transcriptions, it concluded that Tweet Teach enhanced the participants' reading skills, particularly in phonics and vocabulary understanding.

ii. Perceptions in using Tweet Teach in learning reading skill

After they used Tweet Teach for a month, their perception towards using the modules in enhancing their reading skills had gradually changed. Most of the participants preferred using the modules in learning reading skills. Their statements were recorded and transcribed.

I like reading using Tweet Teach as I don't have to worry about long sentences. The words are short and simple. I think I enjoy doing this rather than learning reading in classes. It is way much fun using Tweet Teach! (Syaf)

Maybe the teacher can use the modules and Tweet Teach in class. I think everyone will love reading lessons. (Adam)

The theme was further elaborated in the Likert scale data where four out of five participants were stated they liked learning English using Tweet Teach. Based on the items in the Likert scale, it was evidenced that most participants showed positive perceptions after using the modules in learning reading skills. The improvement of the participants' post test result shown that the modules had significantly impacted the participants in their perception of using Tweet Teach.

Based on the findings and triangulation of data, it is evidenced that the result of the study has fulfilled the aim and answered the research questions.

\section{Discussion}

To summarize the findings, Tweet Teach benefited the low proficiency of Level 1, especially in reading skills. The modules, the 'Tweet Sound' and 'Tweet Pic-a-Thing' for example, has improved the pupils' phonemic awareness. In the modules, the participants learned to spell the words based on the phonetic sounds before they typed them correctly. Some of them had difficulties in identifying the sounds of the individual letters at first, but throughout the sessions, they slowly developed the skills. Yunus, Salehi and Amini (2016) in their study stated that second language learners need to acquire the accurate, relevant skills like the production of phonemes, connected speech, word stress and 
intonation before they can communicate using the language. Participants undoubtedly gained their phonemic awareness as they either spelled the words themselves or listened to the researchers' pronunciation. Another plus point for this learning tool was it promoted the ICT literacy among Level 1 of primary school pupils in the suburban area. Having the opportunity to use the computer and signing up for a Twitter account was a privilege that some pupils might not get in other places. By allowing them to use Tweet Teach in their learning, the participants were proven to be more aware and familiar with the keyboard and the Twitter features. With proper training and regular practice of using ICT in their English learning, pupils are proven to be more confident and motivated in studentcentered classroom. (Yunus, 2007). It goes beyond the conventional chalk and talk classroom, which suggested an interactive and fun way of learning English. Pupils are more exposed to the real world and learning beyond the four wall of the classroom (Tang \& Hew, 2016). Based on the data collection, the participants had positive perceptions on Tweet Teach which led to active participation and engagement in learning English specifically reading skill. Nguyen (2015) advocates that online learning modules benefited the pupils in bringing significant impacts to pupils' learning outcomes. By providing the online learning tool for them in enhancing their reading skill, Tweet Teach also widened the range of vocabulary that the participants learned in a normal classroom. Each letter was important to be recognised as they represented different words, depending on the teachers' creativity and themes. (Jones, Clark \& Reutzel, 2012). Despite the positive side of Tweet Teach, technical issues like the tedious procedure in setting up the Twitter account and limited internet connection at school were among the problems arose throughout the study. The lack of facilities has been an alarming concern to the implementation of the virtual learning tool. (Chua \& Yunus, 2012). Privacy and security issues might be another concern but with proper steps taken, the Tweet Teach will be a great learning tool for low proficient Level 1 pupils in learning reading skill.

\section{Conclusion}

In general, this research has proven that Tweet Teach enhances pupils' reading skills in learning English and encourages positive perceptions in using the modules among the weak learners. One of the findings shows major improvement in the participants' post-test in comparison to their pre test scores. Most participants ticked 'Yes' boxes in the Likert scale, which indicates that they agree to the items stated. From the findings, Tweet Teach provides the pupils the opportunity of maximum exposures on phonic sounds. They were also able to understand the relationship between printed letter and speech sounds. Furthermore, Tweet Teach helped in expanding their vocabulary knowledge by giving maximum attention to the learned vocabulary. It helped to build their foundation of learning. The integration of ICT in learning also promoted excitement in learning where the pupils continued to communicate and assess information thus, making the Tweet Teach relevant and effective.

Tweet Teach has provided a better learning opportunity in enhancing weak pupils' reading skills. Living in a globalization world, using Twitter could help the pupils to improve their reading skills through the interface and features available. Tweet Teach also brings positive perceptions among the pupils as they feel motivated throughout the sessions. However, the disadvantage of the Tweet Teach emerged on the technical part of developing the accounts where it required multiple phone number verification from the researchers. Nevertheless, though limitation exists in the study, the researchers 
INTERNATIONAL JOURNAL OF ACADEMIC RESEARCH IN BUSINESS AND SOCIAL SCIENCES

Vol. 9, No. 1, Jan, 2019, E-ISSN: 2222-6990 (C) 2019 HRMARS

will think of alternatives to utilize the tool with the modules. Future study may focus on getting this tool easily accessible at anytime and anywhere.

\section{Corresponding Author}

Melor Md Yunus, Faculty of Education, National University of Malaysia, Bangi, Selangor Malaysia, Email: melor@ukm.edu.my

\section{References}

Capacho, J. (2016). Teaching and Learning Methodologies Supported by ICT Applied in Computer Science. Turkish Online Journal of Distance Education.

Chua, P. L. \& Yunus, M. M. (2012). ESL teacher and ICT: Teachers' perception. Advances in Language and Literary Studies, Vol. 3 No.1; January 2012.

Creswell, J. W. \& Creswell, J. D. (2017). Research design: Qualitative, quantitative, and mixed methods approaches. Sage publications.

Davis, F. D., Bagozzi, R. P., \& Warshaw, P. R. (1989). User acceptance of computer technology: a comparison of two theoretical models. Management science, 35(8), 982-1003.

Fabre-Merchán, P. Torres-Jara, G. Andrade-Dominguez, F. \& Ortiz-Zurita, M. (2017). A Phenomenological Study: The Impacts of Developing Phonetic Awareness through Technological Resources on English Language Learners'(ELL) Communicative Competences. English Language Teaching, 10(12), 83-87.

Hopkins, D., \& Ahtaridou, E. (1993). A teacher's guide to classroom research.Ibrahim, T. A. (2018). The Role of Technology Acceptance Model in Explaining University Academics' Acceptance and Behavioural Intention to Use Technology in Education. KnE Social Sciences, 3(6), 1162-1172.

Jones, C. D., Clark, S. K. \& Reutzel, D. R. (2012). Enhancing alphabet knowledge instruction : Research implications and practical strategies for early childhood educators. TEaL Faculty Publications. Paper 404.

Legris, P., Ingham, J., \& Collerette, P. (2003). Why do people use information technology? A critical review of the technology acceptance model. Information \& management, 40(3), 191-204.

Ministry of Education Malaysia. (2003). Education Development Plan: 2001 - 2010.

Murugan Raj, T. (2014). The use Of different varieties of Malaysian English among female teenage Malaysians/Murugan Raj A/L Tanaraj (Doctoral dissertation, University of Malaya).

Nikken, P., \& Schols, M. (2015). How and why parents guide the media use of young children. Journal of child and family studies, 24(11), 3423-3435.

Nguyen, T. (2015). The effectiveness of online learning: Beyond no significant difference and future horizons. MERLOT Journal of Online Learning and Teaching: Vol. 11, No. 2, June 2015

Tang, Y. \& Hew, K. H. (2016). Using Twitter for education : Beneficial or simply a waste of time? Computers \& Education 106 (2017) 97-118.

Yunus, M. M. (2007). Malaysian ESL teachers' use of ICT in their classrooms: expectations and realities. ReCALL, 19(01), 79.

Yunus, M. M. \& Salehi, H. (2012). The effectiveness of Facebook groups on teaching and improving writing: Students' perceptions. International Journal of Education and Information Technologies, 1(6), 87-96. 
INTERNATIONAL JOURNAL OF ACADEMIC RESEARCH IN BUSINESS AND SOCIAL SCIENCES

Vol. 9, No. 1, Jan, 2019, E-ISSN: 2222-6990 @ 2019 HRMARS

Yunus, M. M. Nordin, N. Salehi, H. Sun, C. H. \& Embi, M. A. (2013). Pros and cons of using ICT in teaching ESL reading and writing. International education studies, 6(7), 119.

Yunus, M. M., Salehi, H. \& Amini, M. (2016). EFL teachers' cognition of teaching English pronunciation techniques : A mixed-method approach. English Language Teaching; Vol. 9, No.2; 2016 